\title{
Community Participation In Development Of Environmental Impact Analysis Documents (AMDAL) Based On Arnstein Concept
}

\author{
Prita Hapsari Kertaningrum*) and Widayati**) \\ *) Regional office of Ministry of Law and Human Rights in Central Java, E-mail: \\ hapye@yahoo.com \\ **) Faculty of Law, Universitas Islam Sultan Agung Semarang
}

\begin{abstract}
With the enactment of Act No. 11 of 2020 concerning Job Creation, Act No. 32 of 2009 concerning Environmental Protection and Management underwent changes, so that one of the main changes is community participation in the process of preparing the Environmental Impact Analysis (AMDAL) document. This article examines community participation in the preparation of the AMDAL document based on the Job Creation Act according to the concept of community participation by Arnstein. With a normative juridical approach, it can be concluded that community participation in the preparation of AMDAL documents according to the Job Creation Law is included in the second level (Tokenism) meaning that public participation is limited in the form of submitting suggestions, opinions and responses but there is no guarantee that the opinions expressed will be considered in decision-making.

Keywords: Participation; Arnstein; Environment; Analysis.
\end{abstract}

\section{Introduction}

Article 28H of the 1945 Constitution of the Republic of Indonesia, mandates that a good and healthy living environment is a human right of every Indonesian citizen. The declining quality of the environment threatens the survival of human life and living creatures, therefore it is necessary to carry out serious and consistent environmental protection and management by all stakeholders. Environmental protection and management is a systematic and integrated effort carried out to preserve environmental functions and prevent environmental pollution and/or damage which includes pollution, utilization, control, maintenance, supervision and law enforcement. ${ }^{1}$

Act No. 32 of 2009 concerning Environmental Protection and Management (UU PPLH) has provided space for the community to participate in environmental protection and management. The PPLH Law outlines several roles or participation that can be carried out by the community, including social supervision, providing suggestions for opinions, suggestions, objections, complaints and submitting information and/or reports. ${ }^{2}$ One of the forms is community participation in the process of preparing the AMDAL document as stated in Article 26 of the PPLH Law.

With the enactment of Act No. 11 of 2020 concerning Job Creation, the PPLH Law underwent changes. One of the main changes in UUPPLH in the Job Creation

\footnotetext{
1Rasjuddin, Perlindungan Hukum Pidana Terhadap Perusahaan Pertambangan Dalam Penanggulangan Kerusakan Lingkungan, Jurnal Hukum Unissula, Volume 36 No. 1, June 2020, page 2.http://jurnal.unissula.ac.id/index.php/jurnal Hukum/article/view/11180

2 Article 70 paragraph (2) of Act No. 32 of 2009 concerning Environmental Protection and Management.
} 
Law that is highlighted is community participation in the process of preparing Environmental Impact Analysis (AMDAL) documents. Article 26 of the Job Creation Law removes the paragraph regarding the principle of providing transparent and complete information and being notified before activities are carried out, removing objections to AMDAL documents by the public, and removing the existence of the AMDAL Assessment Commission. In addition, the Job Creation Law also changes the paragraph regarding the criteria for the community involved in the process of preparing the AMDAL document.

Community participation is a manifestation of awareness and concern, as well as community responsibility for the importance of environmental management which aims to preserve a good, healthy and well-maintained living environment. Judging from the origin of the word according to John M. Echols \& Hasan Shadily, participation comes from the Latin: "pars" means part; and "capare" means taking part or it can also be called participation or participation or from the English word "participation" which means taking part, participation. ${ }^{3}$

According to I Nyoman Sumaryadi, participation means the participation of a person or community group in the development process, both in the form of statements and in the form of activities by providing input of thoughts, energy, time, capital and/or material expertise, as well as participating in utilizing and enjoying the results of development. ${ }^{4}$ According to Fasli Djalal and Dedi Supriadi, participation can also mean that decision makers suggest groups or communities to be involved in the form of delivering suggestions and opinions, goods, skills, materials and services. Participation can also mean that groups recognize their own problems, examine their options, make decisions, and solve problems. ${ }^{5}$

There are different degrees of community participation, Arnstein suggests 8 (eight) ladders of community participation (Eight Runs on Ladder of Citizen Participation), namely: 6

- Manipulation;

- Therapy;

- Informing (Providing Information);

- Consultation;

- Placation (Appeasement);

- Partnership;

- Delegated power; and

- Citizen control.

In his concept, Arnstein explains that community participation is based on

\footnotetext{
${ }^{3}$ Sil Maria Ungirwalu, Pengaruh Kepemimpinan Kepala Kampung Terhadap Partisipasi Masyarakat Dalam Pembangunan (Studi Di Kampung Wasur Distrik Merauke), Jurnal Ilmu Administrasi dan Sosial "Societas", ISSN 2252-603X, Merauke, 2013, p. 18. http://ejournal.unmus.ac.id/index.php/societas/article/view/257

4I Nyoman Sumaryadi. (2010). Efektifitas Implementasi Otonomi Daerah. Jakarta: Citra Utama, p. 46. ${ }^{5}$ Fasli Djalal \& Dedi Supriadi (eds). (2001). Reformasi Pendidikan dalam Konteks Otonomi Daerah. Yogyakarta: Adicita Karya Nusa, p. 201-202.

6 Isma Rosyida, dkk, Partisipasi Masyarakat Dan Stakeholder Dalam Penyelenggaraan Program Corporate Social Responsibility (Csr) Dan Dampaknya Terhadap Komunitas Perdesaan, Jurnal Transdisiplin Sosiologi, Komunikasi, dan Ekologi Manusia, April 2011, p. 54. https://journal.ipb.ac.id/index.php/sodality/article/view/5832
} 
the power of the community in determining a plan or program. With regard to the typology above, it is divided into 3 major groups, namely:

- No participation;

- The degree of participation/ tokenism/ just a justification to agree; and

- The power of society.

Based on the description above, this paper is intended to examine how community participation in the preparation of the AMDAL document is based on the Job Creation Law and its derivative regulations according to the concept of community participation by Arnstein?

\section{Research Methods}

The approach method used is normative juridical, namely research that is focused on examining the application of rules or norms in positive law. ${ }^{7}$ Normative juridical research puts the law as a building system of norms. The system of norms in question are norms, rules of laws and regulations, and doctrines. The type of data used in this study is secondary data consisting of primary legal materials, secondary legal materials, and tertiary legal materials obtained from books, literature, papers, laws and regulations and other data sources. Secondary data collection is done by searching, collecting, and studying conventional documents such as reading, viewing, listening, or using information technology (internet media). The analytical method used in this paper is a qualitative data analysis method.

\section{Results and Discussion}

\subsection{Community Participation in the Preparation of AMDAL Documents}

One indicator of a healthy environment is that there is no violation of the rights of living things by human activities, whether intentional or unintentional. Environmental damage is not always the result of unlawful acts committed by humans nor is it human error, therefore community participation is needed. ${ }^{8}$

Regulations regarding community participation in the preparation of the AMDAL document are contained in Article 26 and Article 30 of the PPLH Law, with the enactment of the Job Creation Law several regulations related to community participation in the preparation of the AMDAL document have changed, including:

- elimination of the principle of providing information that is transparent, complete and notified before activities are carried out.

- elimination of the community's right to file objections to the AMDAL document.

- the abolition of the AMDAL Assessment Commission.

As the implementing regulation of the Employment Creation Law in the environmental field, PP No.22 of 2021 was issued concerning the Implementation

\footnotetext{
7 Johnny Ibrahim, 2006, Teori dan Metodologi Penelitian Hukum Normatif, Bayumedia Publishing, Malang, p. 295

${ }^{8}$ Carlito Da Costa and Rakhmat Bowo Suharto, Environmental Waste Management System in Effort Creates Sustainable Semarang, Jurnal Daulat Hukum Volume 1 Issue 3 September 2018, p. 850. http://jurnal.unissula.ac.id/index.php/RH/article/view/3413
} 
of Environmental Protection and Management. Based on Article 28 paragraph (2) of PP No.22 of 2021 concerning the Implementation of Environmental Protection and Management, community participation in the preparation of the AMDAL document is carried out before the preparation of the Terms of Reference (KA) form through the announcement of business plans and/or activities as well as the implementation of public consultations.

The form of community participation through the announcement of a business and/or activity plan is the provision of written suggestions, opinions, and responses to the person in charge of the business and/or activity within 10 (ten) working days from the announcement. 9 The announcement of business plans and/or activities is also carried out by the Environmental Feasibility Test Team. In this process, the community can also submit suggestions, opinions, and responses in writing to the Environmental Feasibility Test Team to then be filtered and sorted out suggestions, opinions and responses that are considered relevant to be submitted to the person in charge of the business and/or activity for use in the railway.

The form of community participation through the implementation of public consultations is the provision of suggestions, opinions, and responses to the business plan which later suggestions, opinions, and responses will be recorded in the minutes of the public consultation. ${ }^{10}$

Previously, the procedure for community participation in the AMDAL preparation process based on the PPLH Law was regulated by the Minister of Environment Regulation No.17 of 2012 concerning Guidelines for Community Involvement in the Environmental Impact Analysis Process and Environmental Permits. When compared, both of them regulate community participation through the announcement of business plans and/or activities as well as the implementation of public consultations carried out prior to the preparation of the TOR document with a mechanism for submitting suggestions, opinions and responses. What is different is the existence of the AMDAL Assessment Commission, because one of the components of the membership of this commission is representatives of affected communities. Representatives from affected communities will be selected during the public consultation. ${ }^{11}$ The task of the AMDAL Assessment Commission is to assess the AMDAL document. In the Employment Creation Law and PP No.22 of 2021, the AMDAL Assessment Commission is removed and its task in assessing the AMDAL document is replaced by the Environmental Feasibility Test Team whose membership components consist of elements from the Central Government, Regional Governments, and certified experts, there are no elements of the community affected inside it.

\subsection{Levels of Community Participation According to Arnstein Concept}

\footnotetext{
9 Article 28 paragraphs (3) and (4) of PP No.22 of 2021 concerning the Implementation of Environmental Protection and Management.

10 Article 28 paragraph (5) and (6) of PP No.22 of 2021 concerning the Implementation of Environmental Protection and Management

${ }^{11}$ Chapter II letter c Regulation of the Minister of the Environment No.17 of 2012 concerning Guidelines for Community Involvement in the Process of Environmental Impact Analysis and Environmental Permits.
} 
Community participation is basically a process that involves the community. Community participation is a two-way communication process that takes place continuously to increase the community's full understanding of an activity process in terms of environmental problems and needs being analysed.12Many view community participation solely as the delivery of information (public information), counseling, and even just a public relations tool so that these activities can run without obstacles. Therefore, community participation is not only used as a means to achieve goals, but is also used as an end (participation is an end itself). ${ }^{13}$

The need for community participation was expressed by Prof. Koesnadi Hardjasoemantri, that in addition to providing valuable information to decision makers, community participation will reduce the possibility of people's unwillingness to accept decisions. Furthermore, community participation will help protect the law. If a final decision is taken by taking into account the objections raised, it will reduce the possibility of submitting a case to the court. ${ }^{14}$

According to Cohen and Uphoff (1977) community participation based on systems and mechanisms is divided into four types, namely: ${ }^{15}$

- Participation in Decision Making

is community participation in the process of making organizational decisions and policies which is manifested by community participation in meetings.

- Participation in Implementation

is the participation or participation of the community in development operational activities based on a predetermined program (contributions of thoughts, forms of material donations, and forms of action as project members).

- Participation in Benefits

is community participation in enjoying or utilizing the results of development achieved in the implementation of development.

- Participation in Evaluation

is community participation in the form of participation in assessing and supervising development activities and their results.

The concept of the level of community participation was put forward by Arnstein in 1971. This concept categorizes participation as the power of citizens in influencing changes in policy making. ${ }^{16}$ According to Arnstein, there are 3 (three) levels of participation which are then broken down into 8 (eight) rungs of participation. According to Arnstein, there are 8 (eight) rungs of the public

\footnotetext{
${ }^{12}$ Lalu, Sabardi, Peran Serta Masyarakat Dalam Pengelolaan Lingkungan Hidup Menurut Undangundang Nomor 32 Tahun 2009 Tentang Perlindungan dan Pengelolaan Lingkungan Hidup, Fakultas Hukum Universitas Mataram, Yustisia Vol.3 No. 1, January-April 2014.https://jurnal.uns.ac.id/yustisia/article/view/10120

13 Marpaung ,Leden, 1997, Tindak Pidana Lingkungan Hidup dan Masalah Preverensinya, Sinar Grafika:Jakarta, p.47

14 Hardjasoemantri, Koesnadi, Aspek Hukum Peran Serta Masyarakat Dalam Pengelolaan Lingkungan Hidup, Gajah Mada University Press 1986, Yogyakarta, p.67

15 Siti, Irene, 2011, Desentralisasi Dan Partisipasi Masyarakat Dalam Membayar Pendidikan, Perpustakaan Pelajaran, Yogyakarta, p. 61-63.

${ }^{16}$ Antun Mardiyanta, State of the art: Konsep partisipasi dalam ilmu administrasi publik, Jurnal Masyarakat, Kebudayaan Dan Politik Vol.26 No.4 of 2013, p. 229.http://journal.unair.ac.id/download-fullpapers-mkpca4c173b68full.pdf
} 
participation ladder, namely:

- Manipulation

is the lowest level of participation, where the community is only used by name. Activities to manipulate information to gain public support and promise a better situation even though it will never happen. ${ }^{17}$

- Therapy power holders give reasons for proposals under the guise of involving the community. Although involved in activities, the goal is more to change the mindset of the community than to get input from the community itself. 18

- Informing (Providing Information)

power holders only provide information to the community regarding the proposed activity, the community is not empowered to influence the results. Information may include rights, responsibilities and options, but there is no feedback or negotiating power from the community. Information is provided at the final stages of planning and the community has little opportunity to influence the plans that have been developed. ${ }^{19}$

- Consultation

the public is not only notified but also invited to share opinions, although there is no guarantee that the opinions expressed will be taken into account in decision making. The method that is often used is a survey on the direction of the community's thoughts or community environment meetings and public hearings. ${ }^{20}$

- Placation (Appeasement)

holders of power/government need to appoint a number of influential members of society to become members of a public body, and they have certain access to the decision-making process. Even though in its implementation the community's proposals are still considered however, it is not always implemented because of the relatively low position and fewer in number compared to the members of the power/government holder so they are unable to make decisions. ${ }^{21}$

- Partnership

the community has the right to negotiate with decision makers or the government, by mutual agreement power is shared between the community and the power holder/government. For this reason, an agreement was taken to share responsibilities in planning, controlling decisions, formulating policies and solving problems faced. ${ }^{22}$

- Delegated power

at this level the community is given the authority to make decisions on certain plans. To resolve the problem, the power holder/government must negotiate

17 Sigit Wijaksono, Pengaruh lama tinggal terhadap tingkat partisipasi masyarakat dalam pengelolaan lingkungan pemukiman, Jural ComTech Vol 4 No.1 June 2013, p. 28. https://journal.binus.ac.id/index.php/comtech/article/view/2679

${ }_{18}$ Ibid, p. 28

${ }^{19} \mathrm{Ibid}$

${ }^{20}$ Ibid, p. 28

${ }^{21}$ Ibid

22 Ibid 
with the community without pressure from above, it is possible for the community to have a level of control over the decisions of the power holder/government. ${ }^{23}$

- Citizen control

communities can participate in and control the entire decision-making process. At this level, the community has the power to regulate programs/activities related to their interests. The community has the authority to and can negotiate with outside parties who want to make changes. ${ }^{24}$

3 (three) levels of participation according to Arnstein, namely

- The lowest level is non-participation. Participation activities that occur at this level are actually a distortion of participation. The real purpose is not to support the people to participate but to enable the power holders to simply please the participants. In this level there are two steps, namely Manipulation and Therapy.

- The second level is called Tokenism. It includes three steps, namely the provision of Informing, Consultation, and Placation. This level has indeed involved dialogue activities with the public which means that citizens have the right to have their opinions heard even though they are not directly involved in decision making.

- The highest level is citizen control which provides opportunities for stronger involvement in policy making. Citizens take a direct part in decision-making. This level indicates a redistribution of power from the government/power holders to the community. There are three steps in this level, starting from Partnership, Delegated power, and Citizen control.

Determination of the level of community participation in the preparation of the AMDAL document at the Informing ladder level is based on the fact that the public gets information through the announcement of the business and/or activity plan which includes the name and address of the person in charge, type, scale, location of business and/activity, potential impact on the environment, date of announcement starting to be installed and the deadline for submitting suggestions, opinions, and responses from the public, as well as names and addresses for submitting suggestions, opinions, and responses. ${ }^{25}$

At the Consultation ladder level, it is based that the community is allowed to provide suggestions, opinions and feedback but they do not have the ability to get assurances that their views will be considered by decision makers.

\section{Closing}

Community participation in the preparation of the AMDAL document according to the Job Creation Act and its derivative laws and regulations based on the Arnstein concept is included in the second level, namely Tokenism. As well as being on the 4th rung of the Consultation, meaning that public participation is limited in the form of submitting suggestions, opinions and responses, but there is

\footnotetext{
${ }^{23}$ Ibid, p. 27

24 Ibid

${ }^{25}$ Article 30 PP No.22 of 2021 concerning the Implementation of Environmental Protection and Management.
} 
no guarantee that the opinions expressed will be taken into consideration in decision making. Compared to community participation according to the PPLH Law, community participation is on the 5 th rung of the Placation because there are community representatives who sit on the AMDAL Assessment Commission and have access to the decision-making process. The "ladder of participation" is one way to understand public participation, which shows the relationship between the community and the government in the process of formulating and implementing public policies.

\section{References}

\section{Journal}

[1] Carlito Da Costa and Rakhmat Bowo Suharto, Environmental Waste Management System in Effort Creates Sustainable Semarang, Jurnal Daulat Hukum Volume 1 Issue 3 September 2018, p. 850. http://jurnal.unissula.ac.id/index.php/RH/article/view/3413

[2] Isma Rosyida, dkk, Partisipasi Masyarakat Dan Stakeholder Dalam Penyelenggaraan Program Corporate Social Responsibility (Csr) Dan Dampaknya Terhadap Komunitas Perdesaan, Jurnal Transdisiplin Sosiologi, Komunikasi, dan Ekologi Manusia, April 2011, p. 54. https://journal.ipb.ac.id/index.php/sodality/article/view/5832

[3] Sigit Wijaksono, Pengaruh lama tinggal terhadap tingkat partisipasi masyarakat dalam pengelolaan lingkungan pemukiman, Jural ComTech Vol 4 $\begin{array}{llll}\text { No.1 June 2013, } 28 . & \end{array}$ https://journal.binus.ac.id/index.php/comtech/article/view/2679

[4] Sil Maria Ungirwalu, Pengaruh Kepemimpinan Kepala Kampung Terhadap Partisipasi Masyarakat Dalam Pembangunan (Studi Di Kampung Wasur Distrik Merauke), Jurnal Ilmu Administrasi dan Sosial "Societas", ISSN 2252603X, Merauke, 2013, p. 18. http://ejournal.unmus.ac.id/index.php/societas/article/view/257

[5] Antun Mardiyanta, State of the art: Konsep partisipasi dalam ilmu administrasi publik, Jurnal Masyarakat, Kebudayaan Dan Politik Vol.26 No.4 of 2013, p. 229.http://journal.unair.ac.id/download-fullpapers-mkpca4c173b68full.pdf

[6] Lalu, Sabardi, Peran Serta Masyarakat Dalam Pengelolaan Lingkungan Hidup Menurut Undang-undang Nomor 32 Tahun 2009 Tentang Perlindungan dan Pengelolaan Lingkungan Hidup, Fakultas Hukum Universitas Mataram, Yustisia Vol.3 No. 1, January-April 2014.https://jurnal.uns.ac.id/yustisia/article/view/10120

[7] Rasjuddin, Perlindungan Hukum Pidana Terhadap Perusahaan Pertambangan Dalam Penanggulangan Kerusakan Lingkungan, Jurnal Hukum Unissula, Volume $36 \quad$ No. 1, June 2020, page 2.http://jurnal.unissula.ac.id/index.php/jurnal Hukum/article/view/11180

\section{Book}

[1] Fasli Djalal \& Dedi Supriadi (eds). (2001). Reformasi Pendidikan dalam Konteks Otonomi Daerah. Yogyakarta: Adicita Karya Nusa

[2] Hardjasoemantri, Koesnadi, Aspek Hukum Peran Serta Masyarakat Dalam 
Pengelolaan Lingkungan Hidup, Gajah Mada University Press 1986, Yogyakarta

[3] I Nyoman Sumaryadi. (2010). Efektifitas Implementasi Otonomi Daerah. Jakarta: Citra Utama

[4] Johnny Ibrahim, 2006, Teori dan Metodologi Penelitian Hukum Normatif, Bayumedia Publishing, Malang

[5] Marpaung, Leden, 1997, Tindak Pidana Lingkungan Hidup dan Masalah Preverensinya, Sinar Grafika:Jakarta

[6] Siti, Irene, 2011, Desentralisasi Dan Partisipasi Masyarakat Dalam Membayar Pendidikan, Perpustakaan Pelajaran, Yogyakarta

\section{Regulation}

[1] Act No. 32 of 2009 concerning Environmental Protection and Management.

[2] Act No. 11 of 2020 concerning Job Creation.

[3] PP No.22 of 2021 concerning the Implementation of Environmental Protection and Management.

[4] Minister of Environment Regulation No. 17 of 2012 concerning Guidelines for Community Involvement in the Process of Environmental Impact Analysis and Environmental Permits. 